\title{
Fall Prevention in Community-Dwelling Older Adults
}

Citation for published version (APA):

McCrum, C. (2020). Fall Prevention in Community-Dwelling Older Adults. New England Journal of Medicine, 382(26), 2579-2580. https://doi.org/10.1056/NEJMc2005662

Document status and date:

Published: 25/06/2020

DOI:

10.1056/NEJMc2005662

Document Version:

Publisher's PDF, also known as Version of record

Document license:

Taverne

Please check the document version of this publication:

- A submitted manuscript is the version of the article upon submission and before peer-review. There can be important differences between the submitted version and the official published version of record.

People interested in the research are advised to contact the author for the final version of the publication, or visit the DOI to the publisher's website.

- The final author version and the galley proof are versions of the publication after peer review.

- The final published version features the final layout of the paper including the volume, issue and page numbers.

Link to publication

\footnotetext{
General rights rights.

- You may freely distribute the URL identifying the publication in the public portal. please follow below link for the End User Agreement:

www.umlib.nl/taverne-license

Take down policy

If you believe that this document breaches copyright please contact us at:

repository@maastrichtuniversity.nl

providing details and we will investigate your claim.
}

Copyright and moral rights for the publications made accessible in the public portal are retained by the authors and/or other copyright owners and it is a condition of accessing publications that users recognise and abide by the legal requirements associated with these

- Users may download and print one copy of any publication from the public portal for the purpose of private study or research.

- You may not further distribute the material or use it for any profit-making activity or commercial gain

If the publication is distributed under the terms of Article $25 \mathrm{fa}$ of the Dutch Copyright Act, indicated by the "Taverne" license above, 
$\left(\mathrm{PaCO}_{2}\right)$ and elevated ventilator driving pressure (defined as the difference between plateau pressure and positive end-expiratory pressure [PEEP]). The $\mathrm{PaCO}_{2}$ and $\mathrm{pH}$ did not differ in the two groups during the 7-day intervention. The PEEP was slightly higher in the liberal-oxygen group, but both the plateau and driving pressures were similar in the two groups. We calculated a surrogate of oxygen transport for the 7-day intervention period comprising the hemoglobin level, arterial oxygen saturation, and heart rate, and it did not differ in the two groups. Furthermore, we did not observe any signal of an increased lactate level or increased Sequential Organ Failure Assessment score during follow-up. Several studies that have investigated the relationship between oxygen delivery and oxygen consumption in critically ill patients or patients with sepsis ${ }^{4}$ have not shown differences in outcomes. Oxygen delivery has to decrease to a level below $25 \%$ to reach the anaerobic threshold. ${ }^{5}$ Our findings do not provide any evidence that the hypothesis of acute cor pulmonale and low cardiac output could explain our results.

Gilles Capellier, M.D., Ph.D.

Loic Barrot, M.D.

Marc Puyraveau, M.Sc.

University Hospital Jean Minjoz

Besançon, France

gilles.capellier@univ-fcomte.fr

Since publication of their article, the authors report no further potential conflict of interest.

1. Constantin J-M, Jabaudon M, Lefrant J-Y, et al. Personalised mechanical ventilation tailored to lung morphology versus low positive end-expiratory pressure for patients with acute respiratory distress syndrome in France (the LIVE study): a multicentre, single-blind, randomised controlled trial. Lancet Respir Med 2019;7:870-80.

2. The National Heart, Lung, and Blood Institute PETAL Clinical Trials Network. Early neuromuscular blockade in the acute respiratory distress syndrome. N Engl J Med 2019;380:1997-2008. 3. Mekontso Dessap A, Boissier F, Charron C, et al. Acute cor pulmonale during protective ventilation for acute respiratory distress syndrome: prevalence, predictors, and clinical impact. Intensive Care Med 2016;42:862-70.

4. Heyland DK, Cook DJ, King D, Kernerman P, Brun-Buisson C. Maximizing oxygen delivery in critically ill patients: a methodologic appraisal of the evidence. Crit Care Med 1996;24:517-24.

5. Ronco JJ, Fenwick JC, Tweeddale MG, et al. Identification of the critical oxygen delivery for anaerobic metabolism in critically ill septic and nonseptic humans. JAMA 1993;270:1724-30. DOI: 10.1056/NEJMc2009489

THE EDITORIALIST REPLIES: Cheung and Lam suggest that the use of the prone position could have confounded the results of the trial conducted by Barrot et al. Although the prone position can indeed affect both oxygenation and survival, it was probably a postrandomization event, possibly motivated by the patients' clinical progress. The statistical and clinical interpretation of any analyses that adjust for postrandomization events is difficult in any situation and probably quite problematic in this trial in which the overall sample size was small and the prone position was one of many actions initiated by the bedside clinical team.

Das et al. speculate that in the $\mathrm{LOCO}_{2}$ trial, acute cor pulmonale could have been one mechanism by which the group of patients who were randomly assigned to lower oxygen titration targets may have incurred a worse outcome than those assigned to higher oxygen titration targets. It is certainly one of several possible explanations, assuming the difference was not simply due to chance alone.

Albert and Swenson raise issues regarding the potential role of prerandomization oxygenation strategies and the accuracy of pulse oximetry in ICU-ROX. Although prerandomization oxygenation may be important, the distributions should be balanced in the two groups and therefore should not confound interpretation in the traditional sense. As I mentioned in my editorial, ${ }^{1}$ the limited accuracy of pulse oximetry can complicate the delivery and interpretation of alternative oxygenation strategies.

Derek C. Angus, M.D., M.P.H.

University of Pittsburgh School of Medicine

Pittsburgh, PA

Since publication of his editorial, the author reports no further potential conflict of interest.

1. Angus DC. Oxygen therapy for the critically ill. $\mathrm{N}$ Engl J Med 2020;382:1054-6.

DOI: 10.1056/NEJMc2009489

\section{Fall Prevention in Community-Dwelling Older Adults}

TO THE EDITOR: Ganz and Latham (Feb. 20 issue $)^{1}$ review strategies and evidence regarding fall prevention in older adults and make recommendations for practice. The case vignette de- scribes a woman who has fallen after tripping on uneven pavement, an event that reflects a common cause of fall-related injuries. ${ }^{2}$ Prevention of a fall after a trip requires either the perception 
and avoidance of the obstacle (gait adaptability) or a rapid balance-recovery response (reactive balance control). Neither ability is addressed directly in the assessment of or training for the measures suggested by Ganz and Latham walking speed, standing balance, performance on the Timed Up and Go test, and muscle strength. A recent Cochrane review concluded that highly challenging balance exercises are more specific and most effective for fall prevention, whereas strength training alone is less specific and less effective ${ }^{3}$; this finding reinforces the importance of task specificity in fall prevention. ${ }^{4}$ I hope that the promising results shown in the recent publication of the first large randomized, clinical trial of reactive balance training ${ }^{5}$ encourages clinicians and other practitioners working with older adults to consider a more task-specific approach to their assessment of the risk of falls and their development of interventions.

\section{Christopher McCrum, Ph.D.}

Maastricht University Medical Center

Maastricht, the Netherlands

chris.mccrum@maastrichtuniversity.nl

No potential conflict of interest relevant to this letter was reported.

1. Ganz DA, Latham NK. Prevention of falls in communitydwelling older adults. N Engl J Med 2020;382:734-43.

2. Timsina LR, Willetts JL, Brennan MJ, et al. Circumstances of fall-related injuries by age and gender among community-dwelling adults in the United States. PLoS One 2017;12(5):e0176561. 3. Sherrington C, Fairhall NJ, Wallbank GK, et al. Exercise for preventing falls in older people living in the community. Cochrane Database Syst Rev 2019;1:CD012424.

4. Grabiner MD, Crenshaw JR, Hurt CP, Rosenblatt NJ, Troy KL. Exercise-based fall prevention: can you be a bit more specific? Exerc Sport Sci Rev 2014;42:161-8.

5. Lurie JD, Zagaria AB, Ellis L, et al. Surface perturbation training to prevent falls in older adults: a highly pragmatic, randomized controlled trial. Phys Ther 2020 January 30 (Epub ahead of print).

DOI: 10.1056/NEJMc2005662

TO THE EDITOR: Falls remain a medical hazard among elderly persons, and the fear of falls may confine many able citizens to involuntary solitude. We appreciate the report by Ganz and Latham but would include an additional comment about assistive devices for persons at risk for falls. Specifically, we want to mention the four-wheeled walker (commonly known as a rollator) that can be used both indoors and outdoors. ${ }^{1}$

Since 2000, at least 3\% of the Swedish population regularly use a rollator, including a third of those 80 years of age or older. ${ }^{2} \mathrm{~A}$ rollator can carry personal belongings weighing up to a few kilograms and can be used as a seat to rest on when needed. The device is superior to other walking aids in terms of energy expenditure and walking speed and allows the user to remain an active participant in the local community. ${ }^{3,4}$ The woman in the case vignette should be advised to use a rollator to reduce the risk of falling and continue an active social life.

Kristofer Andréasson, M.D., Ph.D.

Roger Hesselstrand, M.D., Ph.D.

Lund University

Lund, Sweden

kristofer.andreasson@med.lu.se

No potential conflict of interest relevant to this letter was reported.

1. Posse J. Aina Lucia Wifalk: Svenskt kvinnobiografiskt lexikon. Gothenburg, Sweden: University of Gothenburg, 2018 (https://skbl.se/en/article/AinaWifalk).

2. Jonsson L. The importance of the 4-wheeled walker for elderly women living in their home environment - a three-year study. Vallingby, Sweden: Swedish Handicap Institute, 2002 (https://www.cs.cmu.edu/ flo/course-spring03/Swedish_report_ on_Walker.pdf).

3. Löfqvist C, Nygren C, Brandt A, Iwarsson S. Very old Swedish women's experiences of mobility devices in everyday occupation: a longitudinal case study. Scand J Occup Ther 2009;16: 181-92.

4. Mundt M, Batista JP, Markert B, Bollheimer C, Laurentius T. Walking with rollator: a systematic review of gait parameters in older persons. Eur Rev Aging Phys Act 2019;16:15.

DOI: 10.1056/NEJMc2005662

TO THE EDITOR: In their Clinical Practice article about fall prevention in community-dwelling older adults, Ganz and Latham fail to consider postprandial hypotension in the differential diagnosis. Postprandial hypotension - a fall in systolic blood pressure of greater than $20 \mathrm{~mm}$ Hg within 2 hours after a meal - occurs in approximately $20 \%$ of "healthy" older people; the prevalence is even higher among those with disorders associated with autonomic dysfunction. ${ }^{1}$ Postprandial hypotension may be more common than the orthostatic hypotension discussed by Ganz and Latham. Postprandial hypotension has been reported as an independent risk factor for falls ${ }^{2}$ and other adverse sequelae, including death, ${ }^{3}$ even among asymptomatic patients. Although the pathophysiology of postprandial hypotension is heterogeneous, the more rapid the rate of gastric emptying, the greater the decline in blood pressure. ${ }^{1}$ Gastric distension, as induced by drinking water, attenuates the fall in blood pressure. ${ }^{1}$ Current management is suboptimal; 
the alpha-glucosidase inhibitor acarbose, ${ }^{1}$ as well as dietary and pharmacologic strategies that slow gastric emptying, ${ }^{1,4}$ may be beneficial, but further investigation is required before such strategies are implemented. Clinicians should consider screening patients with recurrent falls for postprandial hypotension by administering a glucosetolerance test, usually in the form of a 75-g glucose drink.

Karen L. Jones, Dip.App.Sc., Ph.D.

University of Adelaide

Adelaide, SA, Australia

karen.jones@adelaide.edu.au

John E. Morley, M.B., B.Ch.

Saint Louis University

St. Louis, MO

Michael Horowitz, M.B., B.S., Ph.D.

University of Adelaide

Adelaide, SA, Australia

No potential conflict of interest relevant to this letter was reported.

1. Trahair LG, Horowitz M, Jones KL. Postprandial hypotension: a systematic review. J Am Med Dir Assoc 2014;15:394-409. 2. Aronow WS, Ahn C. Association of postprandial hypotension with incidence of falls, syncope, coronary events, stroke, and total mortality at 29-month follow-up in 499 older nursing home residents. J Am Geriatr Soc 1997;45:1051-3.

3. Fisher AA, Davis MW, Srikusalanukul W, Budge MM. Postprandial hypotension predicts all-cause mortality in older, lowlevel care residents. J Am Geriatr Soc 2005;53:1313-20.

4. Jones KL, Rigda RS, Buttfield MDM, et al. Effects of lixisenatide on postprandial blood pressure, gastric emptying and glycaemia in healthy people and people with type 2 diabetes. Diabetes Obes Metab 2019;21:1158-67.

DOI: 10.1056/NEJMc2005662

TO THE EDITOR: Ganz and Latham did not mention the role of outpatient fall-prevention clinics that are designed to conduct comprehensive assessments of the risk factors for falls in vulnerable populations. Typically, a multidisciplinary team designs a comprehensive care plan that usually includes several tailored interventions, such as gait, strength, or balance training, nutritional support, or combinations thereof. This model of care has been shown in multiple clinical trials to reduce risk factors for falls, such as poor grip strength, poor postural control, and slow gait speed, as well as the fear of falling ${ }^{1}$ and the risk of incident falls ${ }^{2}$ and injurious fractures. ${ }^{3}$

We also disagree with the authors' proposal to use a "modular approach that spreads the assessment over multiple office visits," because the greatest barriers to access health care are physical limitations and difficulties with transportation, ${ }^{4}$ both of which are common situations among older adults with a history of falls. The evaluation of fall risk in a single, comprehensive visit is not only a time-efficient option but is also cost effective; in this regard, fall-prevention clinics are highly desirable.

Ben Kirk, Ph.D.

University of Melbourne

Melbourne, VIC, Australia

Felipe Salech, M.D., Ph.D.

Hospital Clinico Universidad de Chile

Santiago, Chile

Gustavo Duque, M.D., Ph.D.

University of Melbourne

Melbourne, VIC, Australia

gustavo.duque@unimelb.edu.au

No potential conflict of interest relevant to this letter was reported.

1. Phu S, Vogrin S, Al Saedi A, Duque G. Balance training using virtual reality improves balance and physical performance in older adults at high risk of falls. Clin Interv Aging 2019;14:1567-77.

2. Palvanen M, Kannus P, Piirtola M, Niemi S, Parkkari J, Järvinen M. Effectiveness of the Chaos Falls Clinic in preventing falls and injuries of home-dwelling older adults: a randomised controlled trial. Injury 2014;45:265-71.

3. Gomez F, Curcio CL, Brennan-Olsen SL, et al. Effects of the Falls and Fractures Clinic as an integrated multidisciplinary model of care in Australia: a pre-post study. BMJ Open 2019; 9(7):e027013.

4. Nambiar B, Hargreaves DS, Morroni C, et al. Improving health-care quality in resource-poor settings. Bull World Health Organ 2017;95:76-8.

DOI: $10.1056 /$ NEJMc2005662

THE AUTHORS REPLY: We agree with McCrum that balance exercises should be included in all fall-prevention exercise programs, and increasing evidence supports the use of exercises that involve a task-specific training approach. Our review was focused on clinicians in office practice who are not specialized in fall prevention; therefore, we emphasized a basic evaluation that is applicable to the general population of community-dwelling older adults and simple exercises that most people could safely do at home without direct supervision. Patients found to have balance problems during this basic evaluation may be referred to a physical therapist to be considered for reactive balance training.

Andréasson and Hesselstrand note that fourwheeled walkers enable safe community mobility, and we agree. However, before prescribing four-wheeled walkers, clinicians should assess each patient's needs, ability, and environment or, in complex cases, refer the patient to a physical or occupational therapist. Although four-wheeled walkers may have advantages over a cane in preserving natural gait, they also require adequate upper-extremity strength (e.g., to lift the walker 
over a curb), postural control, and the physical and cognitive ability to operate the brakes. ${ }^{1} \mathrm{~A}$ four-wheeled walker is also heavier than a cane and difficult to maneuver in narrow spaces. If the patient described in the case vignette has balance deficits that are mild, she could try a cane and progress to a four-wheeled walker, as appropriate.

Jones and colleagues note that postprandial hypotension is a risk factor for falls; the article they cite shows this association among residents of long-term care facilities, but prospectively collected data that show this finding in a representative sample of community-dwelling older adults, ${ }^{2}$ who are the focus of our article, are lacking. In addition, postprandial hypotension has not been routinely assessed in randomized trials of multifactorial assessment and management that collectively showed a reduction in the rate of falls. ${ }^{3}$

Kirk and colleagues note the importance of fall-prevention clinics as an effective strategy for reducing falls. We agree that these clinics, where available, can streamline the evaluation and management of fall risk. However, given the variation in health system resources worldwide, our review deliberately focused on what (rather than how) care should be delivered. Many clinicians do not have access to a fall-prevention clinic, and given the time and organizational constraints of a busy office practice, completion of a fall evaluation in a single visit may not be feasible. Structuring primary care to require a complete evaluation in one visit could have the unintended consequence of the evaluation not being performed. ${ }^{4}$

David A. Ganz, M.D., Ph.D.

Veterans Affairs Greater Los Angeles Healthcare System Los Angeles, CA

dganz@mednet.ucla.edu

Nancy K. Latham, P.T., Ph.D.

Brigham and Women's Hospital

Boston, MA

Since publication of their article, the authors report no further potential conflict of interest.

1. Anslow R, Pinnington LL, Pratt DJ, Spicer J, Ward CD, Weyman N. Stability and manoeuvrability of wheeled walking frames. Physiotherapy 2001;87:402-12.

2. Jansen S, Bhangu J, de Rooij S, Daams J, Kenny RA, van der Velde N. The association of cardiovascular disorders and falls: a systematic review. J Am Med Dir Assoc 2016;17:193-9.

3. Guirguis-Blake JM, Michael YL, Perdue LA, Coppola EL, Beil $\mathrm{TL}$, Thompson JH. Interventions to prevent falls in communitydwelling older adults: a systematic review for the U.S. Preventive Services Task Force. Rockville, MD: Agency for Healthcare Research and Quality, 2018.

4. Spears GV, Roth CP, Miake-Lye IM, Saliba D, Shekelle PG, Ganz DA. Redesign of an electronic clinical reminder to prevent falls in older adults. Med Care 2013;51:Suppl 1:S37-S43.

DOI: 10.1056/NEJMc2005662

\section{Retraction: Cardiovascular Disease, Drug Therapy, and Mortality in Covid-19. N Engl J Med. DOI: 10.1056/NEJMoa2007621.}

TO THE EDITOR: Because all the authors were not granted access to the raw data and the raw data could not be made available to a third-party auditor, we are unable to validate the primary data sources underlying our article, "Cardiovascular Disease, Drug Therapy, and Mortality in Covid-19." ${ }^{1}$ We therefore request that the article be retracted. We apologize to the editors and to readers of the Journal for the difficulties that this has caused.

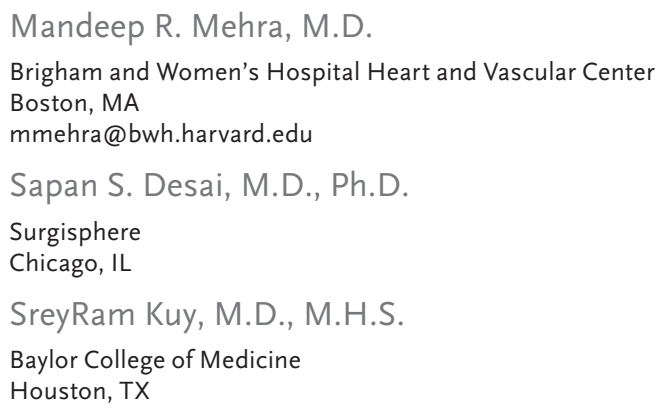

\author{
Timothy D. Henry, M.D. \\ Christ Hospital \\ Cincinnati, $\mathrm{OH}$ \\ Amit N. Patel, M.D. \\ University of Utah \\ Salt Lake City, UT
}

This letter was published on June 4, 2020, at NEJM.org.

1. Mehra MR, Desai SS, Kuy S, Henry TD, Patel AN. Cardiovascular disease, drug therapy, and mortality in Covid-19. N Engl J Med 2020;382:e102.

DOI: 10.1056/NEJMc2021225

Correspondence Copyright (c) 2020 Massachusetts Medical Society.

\section{CORRECTION}

Prevention of Early Ventilator-Associated Pneumonia (N Engl J Med 2020;382:1671-1674). In the third letter in the Correspondence regarding the article by François et al. (page 1672), the first author's surname should have been Llitjos, rather than Llithos. The letter is correct at NEJM.org. 